\title{
Analysis of Speed and Acceleration on 60-Meters Running Test Between Women Soccer and Futsal Players
}

\author{
Indria Herman*, M. Fahmi Hasan, Iwa Ikhwan Hidayat, Tommy Apriantono \\ Mechanical Engineering, Faculty of Mechanical and Aerospace Engineering \\ Sports Science Research Group, School of Pharmacy \\ Institut Teknologi Bandung \\ Bandung, Indonesia \\ *indria.herman@ftmd.itb.ac.id
}

\begin{abstract}
Athlete Speed and acceleration data needed for customizing the athlete training program design. This study is conducted to identify and compare the speed and acceleration of ability between woman Soccer and futsal athlete. The samples used in this study are women soccer and futsal players from Soccer and futsal club, age ranging from 16-17 years old. The athlete performs 60 meters running test, every 10 meters will be recorded the time. Results, Average time $60 \mathrm{~m}$ running test of women soccer $11.16 \mathrm{~s}$ and women futsal $10.50 \mathrm{~s}$, not significant difference with(p>0.05). The average speed of women soccer $5.71 \mathrm{~m} / \mathrm{s}$ and women futsal $5.94 \mathrm{~m} / \mathrm{s}$, not significant difference $\operatorname{with}(p>0.05)$. Average acceleration of women soccer $0.58 \mathrm{~m} / \mathrm{s} 2$ and women futsal $0.61 \mathrm{~m} / \mathrm{s} 2$, not significant difference with(p>0.05). Then, a significant difference in speed and acceleration at each $10,20,40,50,60$ meter between woman Soccer and futsal athlete with $(\mathbf{p}<0.01)$. But, there is no significant difference at 30 meters with a value $(p>0.01)$. The results show there are no significant differences in the time, speed, and acceleration in $60 \mathrm{~m}$ running test between women soccer and futsal athlete. But, there is significant deferent in a change of speed and acceleration per/10 meter. The women futsal players have speed and acceleration higher than football players.
\end{abstract}

Keywords: acceleration, futsal, soccer, speed, women

\section{INTRODUCTION}

In the last two decades, futsal has increased its popularity and evolved into a spectacular sport, involving a massive TV audience [1]. These two sports branches possess very similar features [2]. Soccer and futsal are sports type with their own characteristics, in which there is a complex variety of factors that can influence the performance of a team. Sports Science has contributed in a significant and decisive way, sport, evaluating its characteristics, physical and motor requirements, athletes' profiles, improving and developing more efficient training methods, which aim at achieving better performance and results.

High speed actions during soccer competition are categorized by dividing them into moves requiring acceleration, maximal speed or agility [3]. Futsal player also needs quick strength in very high level in order to move and change place fast within the game, to increase in number in defence and forward, to be effective in one-to-one, to cover distance with/without ball in defense and forward and to exhibit a good technical skill and tactical play [4].

In futsal, some physical qualities which are considered essential, such as aerobic resistance, alactic and lactic anaerobic resistance, localized muscular resistance, potency, time of reaction, flexibility and speed [5]. Soccer has been presenting itself as a sport that is characterized by fast and short movements, in which the displacement with and without the ball demands a high level of physical qualities: explosive strength and aerobic capacity [6].

Speed and acceleration are very important basic abilities in soccer and futsal sports. Athlete Speed and acceleration data are needed for customizing the athlete training program design. Purpose of this study is to identify and compare the speed and acceleration between woman Soccer and futsal athlete. The capability of football player produce varied high-speed actions is known to impact upon football match performance [7]. While high speed actions only contribute to $11 \%$ of total dissonance covered, high-speed movement constitute the more crucial moment of the game and contribute directly to winning possession of the ball and to the scoring or conceding's of goal [8]. Superior performance in varied speed tests of professional players compered to general population, and within higher standard of football, would indicate that certain speed attributes would be advantageous for elite football [9]. Therefore, the purpose of this study to identify and compare the speed and acceleration between woman Soccer and futsal athlete. The findings have potential implications for the training and assessment of physical performance in elite women soccer and futsal player.

\section{METHOD}

Subject group of this study was composed of 10 volunteer futsal players and 10 soccer players. The age range of the sample is 16 to 17 years old. Sample have experience training in a club for two years. Subjects of the study were selected through purposive sampling. In purposive sampling, subjects 
were selected based on several criteria and conditions that the researcher had set to obtain necessary data.

TABLE I. SAMPLE ANTHROPOMETRY DATA

\begin{tabular}{|l|l|l|}
\hline & \multicolumn{1}{|c|}{ Soccer } & \multicolumn{1}{c|}{ Futsal } \\
\hline Age & $16,03 \pm 0.99$ & $17,1 \pm 0,875$ \\
\hline Height $(\mathrm{cm})$ & $156.23 \pm 4.53$ & $161,1 \pm 5,02$ \\
\hline Weight $(\mathrm{kg})$ & $49.11 \pm 7.32$ & $48,6 \pm 4,99$ \\
\hline
\end{tabular}

The measurements were taken in relaxing days during the competition period. Speed and acceleration measurements of the players were conducted in Sarana Olahraga Ganesha. The Athletes performed run test 60 meters, at every 10 meters do the timing that serves to determine the acceleration. The sample conducted 2 trials to take the best time record, with sufficient rest between the first and second trials. All players were informed about the measurements and were asked if they had experienced any injury before. Data analysis was performed after data editing, coding, entry, processing, and cleaning were completed and there was no missing value found. Data analysis was conducted with the help from SPSS 18 application. The technique used in data analysis was descriptive statistics using t-test.

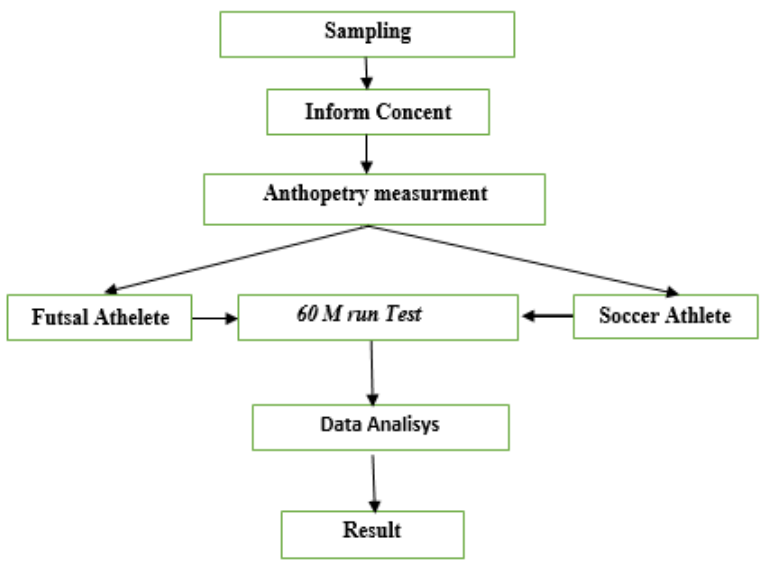

Fig. 1. Recearch flow chart.

\section{RESULT}

Total time $60 \mathrm{~m}$ running test of women soccer team $11.16 \mathrm{~s}$ and women futsal $10.50 \mathrm{~s}$, showed not significant difference with $(\mathrm{p}>0.05)$.

TABLE II. TIME OF 60 METERS RUN TEST

\begin{tabular}{|l|l|l|}
\hline \multicolumn{1}{|c|}{ Distance (m) } & \multicolumn{1}{|c|}{ Soccer $(\mathbf{s})$} & Futsal $(\mathbf{s})$ \\
\hline 0 & 0.000 & 0.00 \\
\hline 10 & 2.823 & 2.50 \\
\hline 20 & 4.258 & 3.83 \\
\hline 30 & 5.895 & 5.70 \\
\hline 40 & 7.702 & 7.36 \\
\hline 50 & 9.460 & 8.90 \\
\hline 60 (Finish Time) & 11.166 & 10.50 \\
\hline
\end{tabular}

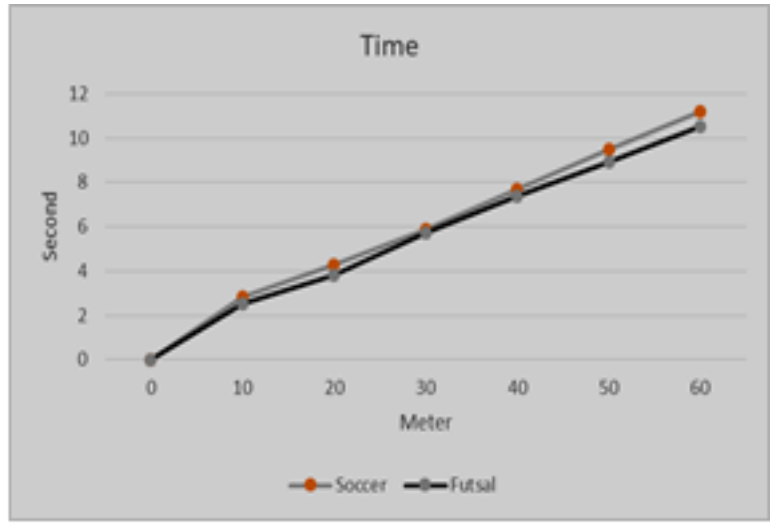

Fig. 2. Time of 60 meters run test.

The average speed of women soccer $5.71 \mathrm{~m} / \mathrm{s}$ and women futsal $5.94 \mathrm{~m} / \mathrm{s}$, not significant difference with $(\mathrm{p}>0.05)$.

TABLE III. SPEED OF 60 METERS RUN TEST

\begin{tabular}{|l|l|l|}
\hline \multicolumn{1}{|c|}{ Distance $(\mathbf{m})$} & \multicolumn{1}{|c|}{ Soccer $(\mathbf{m} / \mathbf{s})$} & Futsal $(\mathbf{m} / \mathbf{s})$ \\
\hline 10 & 3.549 & 3.993 \\
\hline 20 & 7.035 & 7.567 \\
\hline 30 & 6.267 & 5.321 \\
\hline 40 & 5.631 & $6.058^{* *}$ \\
\hline 50 & 5.772 & 6.491 \\
\hline 60 & 6.003 & 6.237 \\
\hline Avarage & 5.710 & 5.944 \\
\hline
\end{tabular}

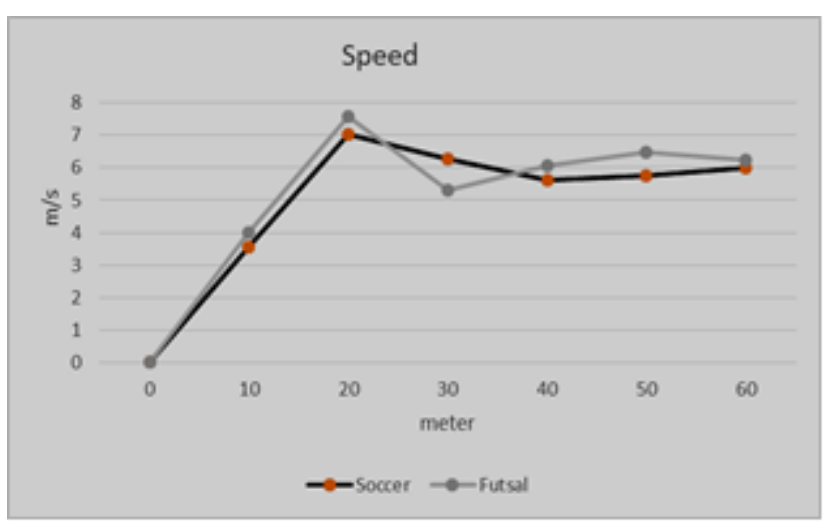

Fig. 2. Speed of 60 meters run test.

Average acceleration of women soccer $0.58 \mathrm{~m} / \mathrm{s} 2$ and women futsal $0.61 \mathrm{~m} / \mathrm{s} 2$, no significant difference with $(\mathrm{p}>0.05)$ Shown in table IV. Then, no significant difference in speed and acceleration at each 10, 20, 40, 50, 60 (m) between woman Soccer and futsal athlete with $(\mathrm{p}>0.01)$. There is significant difference of speed and acceleration at 30 meters with a value $(\mathrm{p}<0.01)$. 
TABLE IV. ACCELERATION OF 60 METERS RUN TEST

\begin{tabular}{|l|l|l|}
\hline \multicolumn{1}{|c|}{ Distance $(\mathbf{m})$} & \multicolumn{1}{|c|}{ Soccer $\left(\mathbf{m} / \mathbf{s}^{\mathbf{2}}\right)$} & \multicolumn{1}{c|}{ Futsal $\left(\mathbf{m} / \mathbf{s}^{2}\right)$} \\
\hline 10 & 1.262 & 1.595 \\
\hline 20 & 2.502 & 2.704 \\
\hline 30 & -0.35883 & $-1198^{* *}$ \\
\hline 40 & -0.26028 & 0.446 \\
\hline 50 & 0.130 & 0.280 \\
\hline 60 & 0.232 & -0.158 \\
\hline Avarage & 0.584 & 0.612 \\
\hline & & $* *=$ Significant different $(\mathrm{p}<0.01)$
\end{tabular}

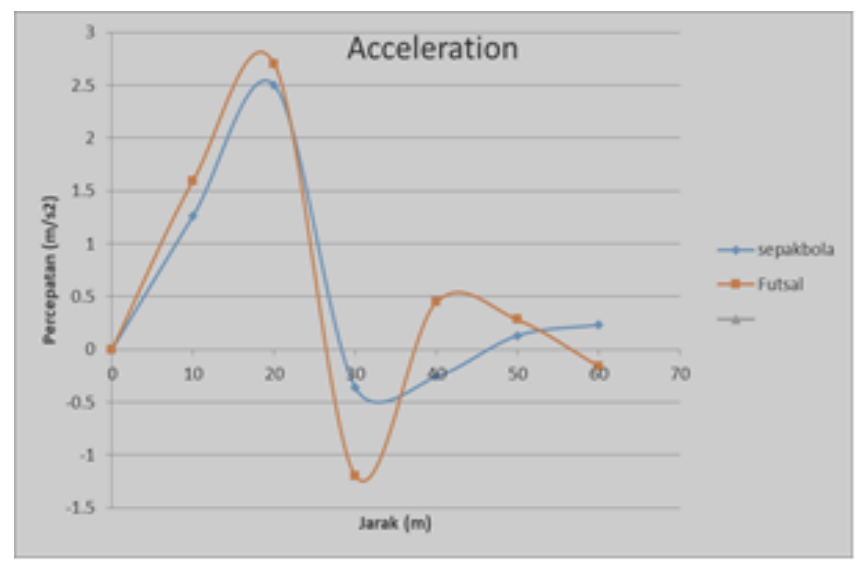

Fig. 3. Acceleration of 60 meters run test.

\section{DISCUSSION}

Soccer and futsal are different sports modalities, but they have common characteristics. The players have similar physical fitness. The speed is a component of the physical capacity which is very used by soccer and futsal athletes, manifesting in many ways, according to the modality, scheme, situation or specific action of the game [9]. Physical ability with an average age of 17 years will not be much difference. Likewise, when viewed from the anthropometry of soccer and futsal players there is no significant difference, in line with previous research conducted in Malaysia which explains the anthropometry of soccer and futsal players, there is no significant difference $[10,11]$. They also play soccer and futsal frequently. The absence of soccer and futsal competitions for under 17 years makes them often practice soccer and futsal. They don't focus on one sport. This causes no significant difference in the physical characteristics of soccer and futsal players in women in the age group of under 17 years. The results of this study are in line with previous research which states that there is no significant difference between the acceleration.

At the test results there are no significant differences in time, speed and acceleration between soccer and futsal athletes. However, together showing the speed and acceleration variables at every 10 meters, there are significant differences between the two branches, where futsal players have a higher speed and acceleration than soccer players. This can occur due to differences in surface and size of the field. In futsal games, players play on smaller fields, futsal players are required to have higher speed and agility than football. And it also affects the players in the environment who are becoming more active and explosive, this is directly not directly hosted by the speed and speed of running a futsal athlete.

\section{CONCLUSIONS}

The results of this study could be a recommendation for Coaches to improve athletes speed and acceleration. There is no difference in speed and acceleration between soccer and futsal players that does not mean the characteristics of football and futsal games similar. But it may be due to the lack of competition in women category.

\section{ACKNOWLEDGMENT}

This research was supported by KEMENRISTEK DIKTI. We thank our colleagues LPPM ITB who provided insight and expertise that greatly assisted the research, although they may not agree with all of the interpretations/conclusions of this paper.

\section{REFERENCES}

[1] A. Roxburgh, "The technician futsal," Newsletter for coaches UEFA, Suppl 4, 2008.

[2] Z. Milanović , G. Sporiš, N. Trajković and F. Fredi Fiorentine, "Differences agility performance between futsal and soccer players," Sport Science, vol. 4(2), pp. 55-59, 2011.

[3] Little and Williams, "Specificity ofacceleration, maximumspeed, andagility inprofessional soccer players," Journal of Strength and Conditioning Research, vol. 19(1), pp. 76-78, 2005.

[4] K. Göral, "Futsal oyunculari ve futbolcularda ivmelenme ve çeviklik özelliklerinin incelenmesi," Akademik Spor Sağlık ve Tıp Bilimleri Dergisi, vol. 10(4), pp. 98-105, 2014.

[5] K. Masuda, N. Kikuhara, S. Demura, S. Katsuta, K. Yamanak, "Relationship between muscle strength in various isokinetic movements and kick performance among soccer players," J Sports Med Phys Fitness, vol. 45(1), pp. 44-52, March 2005.

[6] R.M Philipperts, R. Vaeyers, M. Janssens, "The relationship between peak height velocity and physical performance in youth soccer players," J Sports Sci, vol. 24(3), pp. 221-30, 2006.

[7] E. Kollath and B. Quade, "Measurement of spinting speed of prefessional and amateur soccer player," In Science and Football II, edited by T. Reilly, J. Clarys, and A. Stibbe, London, E and FN Spon, pp. 31-36, 1993.

[8] J. Bangsbo, "The physiology of soccer: with special reference to intense physical exercise," Acta Physiologica Scandinavica, vol. 150, pp. 1-156, 1994.

[9] V.I. Kalapotharakos, N. Strimpakos, I. Vithoulka, C. Karvounidis, K. Diamantopoulos, E. Kapreli, "Physiological characteristics of elite professional soccer teams of different ranking," J Sports Med Phys Fitness, vol. 46(4), pp. 515-9, 2006.

[10] O. Galy, P. Zongo, K. Chamari, A. Chaouachi, A. Dellal, C. Castagna, \& $\mathrm{O}$. Hue, "Anthropometric and physiological characteristics of Melanesian futsal players: a first approach to talent identification in Oceania," Biology of Sport, vol. 32, pp. 135-141, 2015.

[11] J. A. B. de Matos, F. J. Aidar, R. R. Mendes, L. de Malaquias Lômeu, C. A. Santos, R. Pains, V. M. Reis, "ACCELERATION CAPACITY IN FUTSAL AND SOCCER PLAYERS, Fitness \& Performance Journal (Online Edition), vol. 2008. 